Smith, W. (1926). Ann. Surg., 83, 55.

Sohn (Quoted by Stenson, W., 1937)

Stenson, W. (1937). Amer. J. Surg., 37, 334

Walters, W., Gray, H. K., and Priestly, J. T. (1948). Proc. Mayo Clin., 23, 44.

Wangensteen, O. H. (1926). Ann. Surg., 84, 691.

(c) Herniation of Gut, with Strangulation, Through a Hole in the Greater Omentum

Curran, J. W. (1869). Med. Pr., 2, 261.

Hindmarsh, F. D. (1949). British Medical Journal, 2, 1274.

Lisanti, A. (1899). Rif. Med., 2, 303.

Martzloff, K. H. (1930). Surg. Gynec. Obstet., 50, 899.

Sanes, S., and Postoloff, A. V. (1944). Gastroenterology, 3, 30.

\section{FAMILIAL CRISIS IN ACHOLURIC JAUNDICE}

BY

\section{F. GRAHAM MARSON, M.B., M.R.C.P.}

Senior Medical Registrar, General Hospital, Birmingham

M. J. MEYNELL, M.D., M.R.C.P.

Clinical Pathologist, General Hospital, Birmingham

AND

\section{H. TABBUSH, M.B., D.P.H.}

Senior Assistant, Medical Officer of Health, Smethwick

There are on record at least seven instances of spherocytic anaemia in which the haemolytic crisis occurred in a number of members of a family within a short interval (Murray-Lyon, 1935 ; Scott, 1935 ; Dedichen, 1937 ; Damashek, 1941 ; Lyngar, 1942; Horne et al., 19.45; Owren, 1948). We should like to present a series of four cases which occurred in a family of seven.

\section{Case 1}

Thomas C., aged 32, a zinc sprayer, on August 12, 1948, became giddy, had the "shivers," and went to bed. The next morning he awoke perspiring. He got up, but soon after developed dizziness and nausea. On the 14th his doctor considered him to be a case of catarrhal jaundice. Next day the patient arose and nearly collapsed. He was then sent to the Smethwick Fever Hospital as a case of typhoid fever. When seen he complained of abdominal pain. He had noticed that on several occasions his urine was dark.

On examination his temperature was $101^{\circ} \mathrm{F}$. $\left(38.3^{\circ} \mathrm{C}\right.$.), and pulse 80. The conjunctivae had an icteric tinge, and the spleen was enlarged and tender. Blood culture revealed no growth. A blood count on August 16 showed: red cells, 2,700,000; haemoglobin, 55\%; colour index, 1; white cells, 2,300 (polymorphonuclears $50 \%$ ); packed cell volume, $24 \%$; mean cell volume, $88 \mu^{3}$; mean corpuscular haemoglobin concentration, $33 \%$. The urine contained no urobilin.

The patient was transferred to the General Hospital, Birmingham, on August 19 under Professor Thomson. $\mathrm{He}$ was symptom-free and slightly icteric; the spleen was two fingerbreadths below the costal margin; and his knee-jerks were diminished. Otherwise no abnormal physical signs were found. On the day of admission his blood count was as follows: red cells, $1,900,000$; haemoglobin, $40 \%$; colour index, 1.06 ; white cells, 6,300 (neutrophil polymorphonuclears $53 \%$, eosinophils $4 \%$, basophils $1 \%$, lymphocytes $28.5 \%$, monocytes $11 \%$, metamyelocytes $1.5 \%$, Türk cells $1 \%$ ); packed cell volume, $15 \%$; mean cell volume, $80 \mu^{3}$; mean corpuscular haemoglobin concentration, $37 \%$; the red cells showed anisocytosis and spherocytosis; reticulocytes, $0.1 \%$ - two days later they were $0.4 \%$.

The Donath-Landsteiner and acid haemolysin tests were negative. Agglutinations for leptospires were negative. Coombs's test was negative. The patient was Group $\mathbf{O}$ rhesuspositive. Urine at this time showed large amounts of urobilinogen. The serum bilirubin was $0.7 \mathrm{mg}$. per $100 \mathrm{ml}$. ; direct van den Bergh negative ; blood urea, $22 \mathrm{mg}$. per $100 \mathrm{ml}$.; Wassermann reaction doubtful; Kahn test negative.

On August 21, nine days after the onset of illness, a sternal puncture revealed:

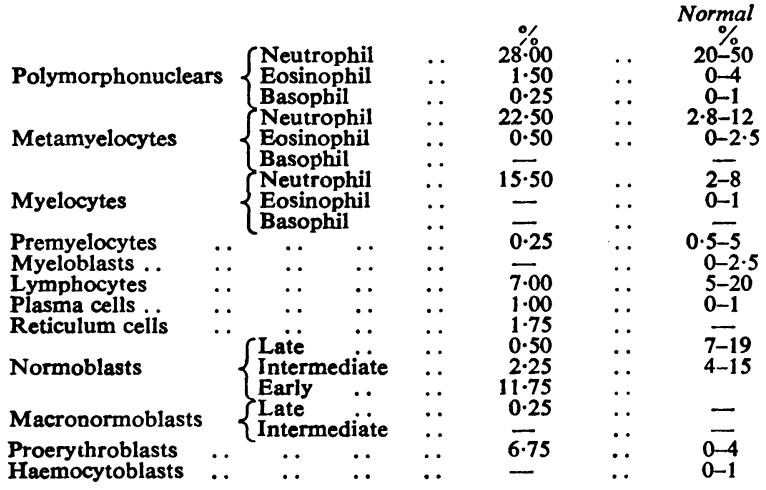

Megakaryocytes were normal in number and appearance. The marrow showed some slight increased cellularity and a shift to the left of the erythroid and myeloid series.

On August 23 his blood count showed a marked change: red cells, 2,810,000; haemoglobin, $50 \%$; colour index, 1.08 ; white cells, 16,100 (polymorphonuclears $52.5 \%$, eosinophils $0.5 \%$, lymphocytes $16.5 \%$, monocytes $4.5 \%$, premyelocytes $0.5 \%$, myelocytes $4.0 \%$, metamyelocytes $21.5 \%$ ) ; reticulocytes, $16.2 \%$; platelets, 439,000 per c.mm. A fragility test showed: commencing haemolysis, $0.60 \%$ saline (control, $0.40 \%$ saline); complete haemolysis, $0.32 \%$ saline (control, $0.32 \%$. saline).

By August 26 his reticulocytes were $25.2 \%$, and on the 30 th his haemoglobin had risen to $72 \%$. A fragility test repeated several weeks later showed: commencing haemolysis, $0.64 \%$ saline (control, $0.44 \%$ saline); complete haemolysis, $0.44 \%$ saline (control, $0.32 \%$ saline).

\section{Case 2}

Thomas C., jun., a schoolboy aged 10 , became ill with vomiting on August 1, eleven days before his father. He complained of headache and pain in the eyes, and was noticed to become rapidly pale. He was admitted to the fever hospital with a diagnosis of meningitis.

On examination he was extremely pale and had a temperature of $99.4^{\circ} \mathrm{F}$. $\left(37.4^{\circ} \mathrm{C}\right.$.). No other abnormal signs were found. The blood culture was sterile. His blood count five days after the beginning of the illness was as follows: red cells, $1,500,000$; haemoglobin, $30 \%$; colour index, 1 ; polymorphonuclears, $77 \%$, with $3 \%$ myelocytes. He was transfused with two pints $(1.14$ litres) of blood, and his condition rapidly improved. The spleen was not palpable. He was transferred to the General Hospital on August 24.

On admission his blood count was: red cells, 3,910,000; haemoglobin, $76 \%$; colour index, 0.97 ; white cells, 14,400 (neutrophil polymorphonuclears $75 \%$, eosinophils 3\%, lymphocytes $17.5 \%$, monocytes $4.5 \%$ ). Films showed anisocytosis, spherocytosis, and some polychromasia. Reticulocytes, $8.4 \%$; platelets, 352,000 per c.mm. He was Group O, rhesus-positive. Coombs's test, the acid haemolysin test, Donath-Landsteiner test, and Wassermann reaction were negative. A fragility test showed: commencing haemolysis, $0.56 \%$ saline (control, $0.44 \%$ saline); complete haemolysis, $0.32 \%$ saline (control $0.28 \%$ saline).

The urine showed an excess of urobilin. Serum bilirubin was $1.1 \mathrm{mg}$. per $100 \mathrm{ml}$. ; blood urea, $72 \mathrm{mg}$. per $100 \mathrm{ml}$. ; and leptospiral agglutinations were negative. The sternal puncture showed increased cellularity. There was no other abnormality.

\section{Cases 3 and 4}

Case 3.- Valerie C., aged 6, first had abdominal pain and vomiting on August 10. She was admitted to the fever hospital on the 16th and found to be extremely pale, with a slight icteric tinge. Her temperature was normal. A blood count showed: red cells, 2,700,000; haemoglobin, $40 \%$; colour index, 0.74 ; 
white cells, 20,600 (polymorphonuclears $50 \%$, metamyelocytes $21 \%$, myelocytes $7 \%$ ). Anisocytosis, poikilocytosis, and polychromasia were present. Thirty-two normoblasts were seen in 200 white blood cells.

Case 4.--Baby Irene, aged 2, was noticed to be off colour for a few days at this time, but her condition did not cause undue alarm. A film done on September 1 showed anisocytosis, spherocytosis, and polychromasia. No other investigations were made.

\section{Other Members of the Family}

Mrs. C. and two daughters, Joan and Mary, were examined as out-patients. Fragility tests, van den Bergh test, reticulocyte count, and stained films were all negative. None of these three had an attack like the other members. A number of relations of Thomas C., sen., were examined. No evidence of spherocytosis was discovered apart from a slight but distinct spherocytosis in his mother.

The family has been kept under observation for over a year. Apart from an increased reticulocyte count and spherocytosis in the affected members, there is nothing to report.

\section{Discussion}

Owren (1948), who reports a series of crises occurring in a family within a short time of each other, gives the most complete observations yet published. In one patient, seen before the crisis began, he was able to study the events throughout. He concludes, with justification, that the crisis should not be called haemolytic, but aplastic. On the fourth day the red cell precursors had almost completely disappeared from the marrow. It was packed with myeloid cells showing maturation arrest with a diminution in segmented polymorphs. The megakaryocytes appeared normal in numbers and appearance. He states that in the crisis the output of urobilinogen in the urine diminishes, as does the serum icteric index. The degree of diminution would obviously depend on the length of the crisis. The crisis is marked by pallor and not icterus. In the case of Thomas $C$., sen., the interesting features are: when first seen he had a low white count and the urine showed no urobilin; when seen by us his reticulocytes were $0.1 \%$ and on the eleventh day after the onset they were $16.2 \%$. This would appear to coincide with the evidence of Owren.

Dacie and Mollison (1943) have shown that the lifespan of the red cell in this condition is less than 14 days. If there is marrow aplasia the red count should be halved in a week. During the crisis some azotaemia results, and blood ureas up to $160 \mathrm{mg}$. per $100 \mathrm{ml}$. are recorded. The cause of the latter, he suggests, is due to renal anoxia.

Dameshek and Bloom (1948) describe similar events in a case of haemolytic anaemia; unfortunately there was no familial evidence of the disease. They claim that the erythroid cells show maturation arrest in the proerythroblast stage at the height of the crisis. It is quite possible that if this case had been studied earlier in the crisis a picture not unlike that reported by Owren might have been found. These authors emphasize the point that the red cells in the peripheral blood were predominantly spherocytic during the crisis, and subsequently, with recovery, there was evidence of macrocytosis and spherocytosis. They use this as evidence for the view that in the crisis there is increased activity of a hypothetical haemolysin producing spherocytes. This assumption is obviously unsound; for if, as had been shown, there is a gross diminution in reticulocytes in the peripheral blood during the crisis the red cells will to a large extent be spherocytes.

Dameshek would explain the crisis as a combination of hypersplenism and a hypothetical haemolysin. Spherocytosis can be produced experimentally by introducing anti-red-cell sera, and is also found in acquired haemolytic anaemias in which a haemolysin can be demonstrated by the Coombs test. Not all acquired haemolytic anaemias showing evidence of a haemolysin produce spherocytosis.

A spherocyte is an old cell. The ageing process may occur rapidly, as in haemolytic anaemias. It is possible to conceive of other factors producing rapid ageing apart from haemolysins. Presumably in familial acholuric jaundice this is an inherited trait. Removal of the spleen does not alter the state of the red cell, which continues spherocytic. Crises usually disappear. In a very few instances recurrences have taken place. It seems acceptable that a condition of hypersplenism exists in this disease and that spherocytosis is a congenital abnormality of rapid ageing which has nothing to do with the activity of haemolysins.

The cause of the crisis still remains to be elucidated. Certainly, when a number of cases occur in a family it would point to an infection having an "incubation period." The common occurrence of gastro-intestinal symptomsfor example, nausea, vomiting, diarrhoea, abdominal pain -would fit in with an intestinal infection. It is known, however, that the haemolytic process, as produced experimentally, will cause a rise in temperature.

\section{Summary}

A series of crises is recorded in a family, four members of which were shown to have spherocytic anaemia of the familial type. All but one recovered spontaneously. Transfusion of two pints of blood was required in one case.

We wish to thank Professor A. P. Thomson for permission to publish; Dr. R. Gaddie for biochemical examinations; Dr. W. Weiner for rhesus typing and the Coombs tests; Miss E. Tacon, senior technician, for carrying out numerous haematological investigations; and Miss P. M. Weight, secretary, for her efforts in compiling and typewriting.

\section{REFERENCES}

Dacie, J. V., and Mollison, P. L. (1943). Lancet, 1, 550

Damashek, W. (1941). New Engl. J. Med., 224, 52.

Dameshek, E., and Bloom, M. L. (1948). Blood, 3, 1381.

Dedichen, H. G. (1937). Norsk Mag. Laegevidensk. 98, 279. Abstract in British Medical Journal, 1937, 1, Epit. 73.

Horne, J. L., Lederer, H., Kirkpatrick, H. J. R., and Leys, D. G. (1945). Lancet, 2, 33 .

Lyngar, E. (1942). Nord. Med., 14, 1246

Murray-Lyon, R. M. (1935). British Medical Journal, 1, 50.

Owren, P. A. (1948). Blood, 3, 231.

Scott, A. M. (1935). Lancet, $2,872$.

The National Smoke Abatement Society celebrated its 21st birthday by holding its annual conference at Margate on September 27-29. In addition to discussions on railway smoke, and on domestic smoke prevention, particularly in the new towns, an afternoon was devoted to two papers on respiratory disease and atmospheric pollution. In one of them, Mr. R. E. Waller, of the Department of Pathology at St. Bartholomew's Hospital, pointed out that such carcinogenic substances as arsenic and 3:4-benzpyrene are known to occur in smoke from burning coal and in domestic soot, and described experiments to measure the 3:4-benzpyrene concentration in the atmosphere at different times of the year. It is highest during the winter, especially during fog, when the concentration may rise to $33 \mu \mathrm{g}$. per 100 cubic metres of air, and down to 1-2 $\mu \mathrm{g}$. in the summer. It seems fairly certain that the source is the inefficient combustion of coal in the ordinary domestic fire, rather than the chimneys of properly working industrial furnaces and power stations, and the amount of benzpyrene in road dust and motor vehicle exhaust smoke is quantitatively small compared with that from coal. Atmospheric benzpyrene is present in the air in smoke particles and not appreciably as free vapour, and it is therefore important to know the size of these particles before being able to estimate the chance of the carcinogen reaching the lung tissue and being retained there. Until this fact is available, the relation of smoke to cancer of the lung will remain unsettled. 